\title{
Manejo anestésico en un paciente con masa mediastinal y síndrome de vena cava superior
}

\author{
Paredes Alviso T. ${ }^{1}$, Icardi G. ${ }^{1}$, De Rosa Y. ${ }^{1}$, Méndez V. ${ }^{1}$, Katzeff A. ${ }^{1}$, Roca A. ${ }^{1}$, Fernández Lapadou L. ${ }^{1}$, Mamani \\ Zárate M. ${ }^{1}$, Fondevilla J. ${ }^{1}$, Molina M. ${ }^{1}$ \\ 1 Hospital Carlos G. Durand, CABA, Argentina.
}

Introducción: Las masas mediastinales anteriores generan compromiso ventilatorio por compresión mecánica de la vía aérea y alteraciones hemodinámicas de grado variable por colapso de los grandes vasos, que determinan un desenlace fatal de no ser previstos. Es fundamental estratificar el riesgo y planificar la estrategia anestésica.

Se presenta el caso de una paciente con síndrome linfoproliferativo y masa mediastinal en plan quirúrgico para biopsia y diagnóstico.

Resumen clínico: Paciente de sexo femenino de 20 años de edad con ortopnea, dolor precordial y síntomas B de un mes de evolución. Presenta radiografía y Tomografía de tórax con masa mediastinal anterior y colapso parcial de bronquio fuente derecho. Se programa biopsia quirúrgica e inicio de corticoterapia en altas dosis.

En quirófano, se procede a sedación para intubación vigil, la paciente evoluciona con edema en esclavina, desaturación y bradicardia extrema con ventilación inefectiva. Se procede a intubación orotraqueal (IOT), se administra $1 \mathrm{mg}$ de atropina endovenoso y expansión con fluidos constatándose reversión del cuadro. Se lleva a cabo procedimiento quirúrgico y posterior traslado a Terapia Intensiva.

Discusión: Los pacientes con diagnóstico de masa mediastinal anterior deben ser estratificados en riesgo bajo o alto mediante signos clínicos, imágenes complementarias y estudio funcional respiratorio. Se destacan la ortopnea, edema en esclavina, diámetro traqueal, compresión bronquial o carinal, obstrucción de vena cava y espirometría con valor menor del $50 \%$ al predicho en posición supina.

Se debe priorizar el uso de anestesia local o citorreducción prequirúrgica. De ser necesaria anestesia general, mantener la ventilación espontánea mediante IOT vigil con paciente semisentado, utilizando fibrobroncoscopio. Evitar el uso de relajantes neuromusculares hasta asegurar la vía aérea, habiendo sorteado la obstrucción. Se recomienda colocar accesos venosos en miembros inferiores y medición invasiva de tensión arterial.

Conclusiones: La evaluación preoperatoria de pacientes con masas mediastinales debe ser multidisciplinaria, valorando signos clínicos y estudios por imágenes. Es fundamental aplicar el procedimiento menos invasivo posible y preservar la ventilación espontánea. De requerirse anestesia general, es vital una adecuada planificación anestésicoquirúrgica.

https://doi.org/10.25237/congresoclasa2019.65 